UDC 612.017.1

\title{
THERMODYNAMICS OF INTERACTION BETWEEN POLYREACTIVE IMMUNOGLOBULINS AND IMMOBILIZED ANTIGEN
}

\author{
S. A. BOBROVNIK ${ }^{1 凶}$, O. V. OGLOBLYA ${ }^{2}$, \\ M. O. DEMCHENKO', S. V. KOMISARENKO \\ ${ }^{1}$ Palladin Institute of Biochemistry, National Academy of Sciences of Ukraine, Kyiv; \\ ${ }^{2}$ ESC Institute of Biology and Medicine, \\ Taras Shevchenko National University of Kyiv, Ukraine; \\ e-mail: s-bobrov@ukr.net
}

Received: 22 April 2021; Accepted: 22 September 2021

In order to determine thermodynamic parameters of the interaction between polyreactive immunoglobulins (PRIGs) and immobilized antigen, several of experimental kinetic curves of PRIGs binding to immobilized ovalbumin were obtained at different temperatures. This allowed determining the rate constants for every step of the binding process for each temperature. Then, using appropriate equations, thermodynamic parameters, such as activation energy, enthalpy, entropy, and standard free energy (Gibbs energy), were calculated. Thermodynamic values obtained show that the main energy consuming step in the study process of PRIGs bindingis the transformation of "inactive" PRIGs into "active" PRIGs, i.e. formation of hydrophobic patches on the surface of PRIGs molecules. In contrast, the following step of the binding of "active" PRIGs to an immobilized antigen is not an energy dependent process.

Keywords: polyreactive immunoglobulins, antigens, kinetics of interaction, rate constants, thermodynamic parameters.

$\mathrm{T}$ he mechanism of interaction between specific antibodies and antigens, its kinetics and thermodynamics are well-studied processes [1]. However, the discovery of PRIGs, which are capable of non-specific binding to a variety of unrelated antigens, raised the question about the mechanism of this interaction, as well as thermodynamics of the process. Despite the fact that the study of PRIGs (which in the literature are more often referred to as polyreactive antibodies, which is not quite correct) has recently been given more and more attention [2-11], the above questions have not yet been solved, although they are of a great interest.

We have previously established that the interaction of PRIGs with antigens is a process that is much more complex than the interaction of specific antibodies with the antigen, as well as the fact that this process is much more temperature dependent than that of specific antibodies with the corresponding antigen [12]. The elucidation of the mechanism of interaction between PRIGs and antigens made it possible to describe the dynamics of this process by means of a system of differential equations. The solution of these equations made it possible to obtain algebraic expressions describing the dynamics of PRIG concentration changes at various stages of PRIG-antigen interaction [13].

Later, we proposed a way to numerically solve these complex equations, which were both transcendental and irrational. It is known that such equations do not have an analytical solution, but they can be solved using numerical methods and a computer. The possibility to find a numerical solution of these equations allowed us to find the values of the rate constants of each of the interaction stages, using the experimental curves of the PRIG binding dynamics to the immobilized antigen [13], which depends on the temperature. Finally, the analysis of the dependence

(c) 2021 Bobrovnik S. A. et al. This is an open-access article distributed under the terms of the Creative Commons Attribution License, which permits unrestricted use, distribution, and reproduction in any medium, provided the original author and source are credited. 
of these rate constants on temperature made it possible to calculate the thermodynamic parameters of the interaction of PRIG with the immobilized antigen. The results of these studies are presented below.

\section{Materials and Methods}

PRIGs were obtained by transformation of control (not immune) BALB/c mice serum by incubation of this serum with $3.5 \mathrm{M}$ KSCN during 5 min at $25^{\circ} \mathrm{C}$ and subsequent dilution of this mixture 1000-5000 times with physiological buffered solution (PBS, $\mathrm{pH}$ 7.2). It was shown earlier [12], that such treatment of serum immunoglobulins results in transformation of the majority of them into PRIGs that are able to bind nonspecifically to various antigens. These PRIGs were used to study their binding to antigen (ovalbumin, Sigma, USA) immobilized on polystyrene plates.

Ovalbumin was immobilized on polystyrene plates by the method developed by us before, which increases the hydrophobicity of proteins being adsorbed on polystyrene surface [14]. Briefly, ovalbumin solution $(0.1 \mathrm{mg} / \mathrm{ml})$ in $1 \%\left(\mathrm{NH}_{4}\right)_{2} \mathrm{CO}_{3}$ with added $0,01 \% \mathrm{NaN}_{3}$ was placed in the wells of polystyrene plates and then dried out in a thermostat at $37^{\circ} \mathrm{C}$. Plates were carefully washed by tap water with subsequent PBS washing to remove poorly associated ovalbumin molecules immediately before experiment, and were used for the study of PRIGs binding. As it was shown before [15], this method of protein immobilization allows obtaining the layer of the partially denatured molecules associated with polystyrene. Such immobilized protein molecules exhibit hydrophobic areas on their surfaces, allowing to study nonspecific PRIGs binding.

PRIGs bound to immobilized ovalbumin was determined by ELISA as it has been described previously [16]. For this purpose, plates with bound PRIGs were incubated with 1:2000 diluted in PBS + 0.1\% Tween 20 (TBS) horseradish peroxidase-conjugated goat anti-mouse IgG antibodies (Sigma, USA) during $60 \mathrm{~min}$ at $4^{\circ} \mathrm{C}$. Then, after careful washing from unbound conjugates, the substrate for peroxidase, namely, the solution of o-phenylenediamine $(1 \mathrm{mg} /$ $\mathrm{ml}$ ) in $0.01 \mathrm{M}$ phosphate buffer (pH 5.0) and $0.003 \%$ $\mathrm{H}_{2} \mathrm{O}_{2}$ solution was added to plates. The reaction was stopped after color developing by adding $0.05 \mathrm{ml}$ 2 M sulfuric acid per wells, and optical density of solutions was measured by microphotocolorimeter ELx800, BIO-TEK, at wave length of $490 \mathrm{~nm}$.

It was shown earlier [17] that in order to use the units of absorption instead of the real PRIGs con- centrations we had to do preliminary experiments to determine the initial PRIGs dilutions which allow us to obtain 2-fold, 4-fold, 8-fold etc. decrease of absorption with 2-fold, 4-fold, 8-fold etc. increase of dilution, respectively. In this study, according to our pilot experiments, PRIGs concentrations in binding experiments performed at $0^{\circ} \mathrm{C}$ should exceed those at $37^{\circ} \mathrm{C}$ by 30 times.

In order to allow reaching the state of equilibrium between an amount of "active" and "inactive" PRIGs in the studied PRIGs solutions, we prepared appropriate PRIGs solutions at $4^{\circ} \mathrm{C}$ and incubated them during 18-20 hours before the experiment, followed by incubation at the appropriate temperature for at least $2 \mathrm{~h}$. After such incubation, the samples of PRIGs were placed in the wells of plates with adsorbed antigen in different time intervals in order to finalize the different incubation periods simultaneously. After finishing the incubation PRIGs solutions in plates, the solutions with unbound PRIGs were removed from the wells by the plates shaking and subsequent rinsing. Finally, plates were treated, as described earlier, by peroxidase-conjugated anti-Ig serum, and the amount of PRIGs bound to ovalbumin was determined by ELISA.

The acquired curves of PRIGs binding at different temperatures were used to determine the rate constants of this process by the method described below.

Mathematical derivations. In order to determine activation energy, $E_{a}$, for each step of PRIGs binding to an antigen one can use the Arrhenius equation:

$$
k=A \cdot e^{-\frac{E a}{R T}}
$$

Where $k$ is the rate constant; $R$ is the gas constant $\left(R=8.314 \mathrm{~J} \cdot \mathrm{K}^{-1} \cdot \mathrm{mol}^{-1}\right)$; $\mathrm{T}$ is reaction absolute temperature (in Kelvins).

From (1) it follows that

$$
\ln k=\ln A-\frac{E_{a}}{R T} .
$$

Thus, the Arrhenius plot can be obtained by plotting the logarithm of the rate constant, $k$, versus the inverse temperature, $1 / \mathrm{T}$, and the slope of this linear plot is equal to $E_{\mathrm{a}}$.

It is known [18] that the Van't Hoff equation relates a temperature-dependent change in equilibrium constant, $K_{\mathrm{e}}$, to its standard enthalpy, $\Delta H^{\circ}$ :

$$
\frac{d \ln K_{e}}{d T}=\frac{\Delta H^{o}}{R T^{2}}
$$


Integration of Eq. (3) gives the following relation between the value of standard enthalpy $\Delta H^{\circ}$ and the reaction temperature $T_{1}$ and $T_{2}$ :

$$
\Delta H^{o}=\frac{R T_{1} T_{2} \ln \frac{K_{e 2}}{K_{e 1}}}{T_{2}-T_{1}}
$$

where $K_{\mathrm{e} 1}$ and $K_{\mathrm{e} 2}$ - equilibrium constants at temperatures $\mathrm{T}_{1}$ and $\mathrm{T}_{2}$, correspondingly.

The same relation can be obtained by a quite different way. According to the main equation of thermodynamics we have:

$$
\Delta G^{\circ}=\Delta H^{\circ}-\mathrm{T} \Delta S^{\circ} .
$$

Where $\Delta G^{0}$ is the change of standard free energy (Gibbs energy) and $\Delta S^{\circ}$ is the change of standard entropy at a given temperature $\mathrm{T}$.

Taking into account that

$$
\Delta G^{0}=-\mathrm{RT} \ln K_{\mathrm{e}}
$$

then the following two equations can be obtained for two different temperatures, $\mathrm{T}_{1}$ and $\mathrm{T}_{2}$ :

$$
\left\{\begin{array}{l}
-\mathrm{RT}_{1} \ln \mathrm{K}_{\mathrm{e} 1}=\Delta H^{o}-\mathrm{T}_{1} \Delta S^{o} \\
-\mathrm{RT}_{1} \ln \mathrm{K}_{\mathrm{e} 2}=\Delta H^{o}-\mathrm{T}_{2} \Delta S^{o}
\end{array}\right.
$$

Algebraic solution of Eqs. (7) allows one to get not only the same formula as Eq. (4) for $\Delta H^{\circ}$ evaluation, but also to obtain the following expression for $\Delta S^{\circ}$ calculation:

$$
\Delta S^{o}=\frac{R T_{2} \ln K_{e 2}-R T_{1} \ln K_{e 1}}{T_{2}-T_{1}} .
$$

If values of $K_{\mathrm{e} 1}$ and $K_{\mathrm{e} 2}$ are known at different temperatures $T_{1}$ and $T_{2}$, using Eqs. (4), (6), and (8) one can also determine the values of thermodynamics characteristics $\Delta H^{\circ}, \Delta G^{\circ}$, and $\Delta S^{\circ}$. The accuracy of $\Delta H^{\circ}$ and $\Delta S^{\circ}$ determination could be increased if one can do several measurements of $K_{\mathrm{e}}$ at correspondent temperatures $T_{i}$. In this case we can represent Eqs. (4) and (8) as following:

$$
\begin{gathered}
R T_{1} T_{2} \ln \frac{K_{e 2}}{K_{e 1}}=\Delta H^{o}\left(T_{2}-T_{1}\right) \\
R T_{2} \ln K_{\mathrm{e} 2}-R T_{1} \ln K_{\mathrm{e} 1}=\Delta S^{\mathrm{o}}\left(T_{2}-T_{1}\right) .
\end{gathered}
$$

From Eq. (9) it follows that the plot $R T_{1} T_{2} \ln \frac{K_{e 2}}{K_{e 1}}$ versus values $\left(T_{2}-T_{1}\right)$ should be a straight line with the slope $\Delta H^{\circ}$. Thus, building this plot for several points $T_{i}$ and measuring its slope allows to determine $\Delta H^{\circ}$ with high accuracy.

The same is also true for the calculation the values of $\Delta S^{\circ}$. According to Eq. (10), $\Delta S^{\circ}$ is equal to the slope of linear plot for the relation between $R T_{2} \ln K_{\mathrm{e} 2}-R T_{1} \ln K_{\mathrm{e} 1}$ and $\left(T_{2}-T_{1}\right)$.
The mechanism of nonspecific interaction between PRIGs and any immobilized antigen [13] was determined earlier and the following scheme of this interaction was proposed:

$$
\mathrm{N} \underset{\mathrm{k}_{2}}{\stackrel{\mathrm{k}_{1}}{\rightleftharpoons}} \mathrm{A} \stackrel{\mathrm{k}_{3}}{\longrightarrow} \mathrm{C},
$$

where $N$ - concentration of "inactive" PRIGs in the solution; $A$ - concentration of "active" PRIGs in the solution; $C$ - concentration of PRIGs bound to immobilized antigen; $k_{1}$ - rate constant of the transformation of "inactive" PRIGs into "active" PRIGs; $k_{2}$ - rate constant of the transformation of "active" PRIGs into "inactive" PRIGs; $k_{3}$ - rate constant of the binding of "active" PRIGs to immobilized antigen.

The following system of differential equations describes such interaction:

$$
\left\{\begin{array}{c}
\frac{d N}{d t}=k_{2} A-k_{1} N \\
\frac{d A}{d t}=k_{1} N-\left(k_{2}+k_{3}\right) A \\
\frac{d C}{d t}=k_{3} A
\end{array}\right.
$$

The solution of the system of differential equations (12) results in equation (13) that describes the dynamics of PRIGs bounding to immobilized antigen, i.e. the value of $C$ :

$$
\begin{aligned}
& C=\mathrm{S}-\frac{S\left(r_{2}+k_{3}\right)\left(r_{1}+k_{2}+k_{3}\right)}{\left(k_{1}+k_{2}\right)\left(r_{2}-r_{1}\right)} e^{r_{1} t}- \\
& -\frac{S\left[k_{2}\left(r_{2}-r_{1}\right)-\left(r_{2}+k_{3}\right)\left(r_{1}+k_{2}+k_{3}\right)\right]}{\left(k_{1}+k_{2}\right)\left(r_{2}-r_{1}\right)} e^{r_{2} t}- \\
& -\frac{k_{1} S\left(r_{2}+k_{3}\right)}{\left(k_{1}+k_{2}\right)\left(r_{2}-r_{1}\right)} e^{r_{1} t}- \\
& -\frac{k_{1} S\left[k_{2}\left(r_{2}-r_{1}\right)-\left(r_{2}+k_{3}\right)\left(r_{1}+k_{2}+k_{3}\right)\right]}{\left(k_{1}+k_{2}\right)\left(r_{2}-r_{1}\right)\left(r_{2}+k_{2}+k_{3}\right)} e^{r_{2} t,}
\end{aligned}
$$

where

$$
\begin{aligned}
& r_{1}=\frac{-\left(k_{1}+k_{2}+k_{3}\right)+\sqrt{\left(k_{1}+k_{2}+k_{3}\right)^{2}-4 k_{1} k_{3}}}{2} ; \\
& r_{2}=\frac{-\left(k_{1}+k_{2}+k_{3}\right)-\sqrt{\left(k_{1}+k_{2}+k_{3}\right)^{2}-4 k_{1} k_{3}}}{2} ;
\end{aligned}
$$

$S$ is the total amount of PRIGs in the study solution, i.e. $S=N+A+C$.

Then, using Eq. (13) and experimental kinetic curves of nonspecific PRIGs binding to an immobilized antigen that were obtained at different temperatures allows us to determine the values of the rate constants $k_{1}, k_{2}$ and $k_{3}[13]$.

Let's denote $Y(t)=C(t) / S$, then, after some simple transformations, this function can be written in the form (14).

It's easy to see 


$$
Y(t)=1-\mathrm{e}^{-\frac{1}{2}\left(k_{1}+k_{2}+k_{3}\right) t}\left(\begin{array}{l}
\cosh \left(\frac{1}{2} \sqrt{\left(k_{1}+k_{2}+k_{3}\right)^{2}-4 k_{1} k_{3} t}\right)+ \\
\frac{\left(\left(k_{1}+k_{2}\right)^{2}+\left(k_{2}-k_{1}\right) k_{3}\right) \sinh \left(\frac{1}{2} \sqrt{\left(k_{1}+k_{2}+k_{3}\right)^{2}-4 k_{1} k_{3} t}\right)}{\left(k_{1}+k_{2}\right) \sqrt{\left(k_{1}+k_{2}+k_{3}\right)^{2}-4 k_{1} k_{3}}}
\end{array}\right)
$$

$$
-\frac{Y^{\prime \prime}(0)}{Y^{\prime}(0)}=k_{3}
$$

$$
k_{1}\left(\frac{k_{3}}{Y^{\prime}(0)}-1\right)=k_{2} \text {. }
$$

For non-linear fitting of curve (Eq. 14) to experimental data seed values $\left(\bar{k}_{1}, \bar{k}_{2}, \bar{k}_{3}\right)$ close to the accurate values $\left(k_{1}, k_{2}, k_{3}\right)$ should be provided. For the task of finding seed values we interpolated the experimental data and find the first and second derivatives of the interpolation function $Y_{\text {interp }}(t)$ at zero time. From (15) we obtain the following formula for the seed value

$$
\bar{k}_{3}=-\frac{Y_{\text {interp }}{ }^{\prime \prime}(0)}{Y_{\text {interp }}{ }^{\prime}(0)} .
$$

Because $r_{1}>r_{2}$ then for large values of time $t>t_{\text {plato }}$, when the function has almost reached a plateau $Y(t) \approx 1$ (and experimental data for this area are usually already lacking, because it can happen after a significant interval of time, for example after a week), the most essential for the logarithmic derivative $\frac{d \ln (1-Y(t))}{d t}$ is the term with algebraically greater value of the decrements in exponents (Eq. 13). This is the term with the lesser modulus (the numbers $r_{1}$, $r_{2}$ are negative), i.e. $r_{1}$. Since $Y(t)=1-A_{1} e^{r_{1} t}-A_{2} e^{r_{2} t}$ and $\frac{d \ln (1-Y(t))}{d t}=\frac{A_{1}\left(r_{1}-r_{2}\right)}{A_{1}+A_{2} \mathrm{e}^{\left(r_{2}-r_{1}\right) t}}+r_{2}$ at large values of time the exponent in the denominator tends to zero under the condition $r_{1}>r_{2}$, we obtain the value $r_{1}$. This allows us to estimate the seed value of the parameter $\overline{r_{1}}$ :

$$
\begin{aligned}
& \overline{r_{1}}=\left.\frac{d \ln (1-Y(t))}{d t}\right|_{t=t_{\text {plato }}} \\
& \text { But } r_{1}=\frac{-\left(k_{1}+k_{2}+k_{3}\right)+\sqrt{\left(k_{1}+k_{2}+k_{3}\right)^{2}-4 k_{1} k_{3}}}{2},
\end{aligned}
$$

let's substitute here the value for the seed value of the parameter $\bar{k}_{2}=\bar{k}_{1}\left(\frac{\bar{k}_{3}}{Y_{\text {interp }}^{\prime}(0)}-1\right) \bar{k}_{1}$ and we get
$\bar{k}_{1}$ :

$$
\bar{k}_{1}=-\frac{Y_{\text {interp }}^{\prime}(0) \bar{r}_{1}\left(\bar{k}_{3}+\bar{r}_{1}\right)}{\bar{k}_{3}\left(Y_{\text {interp }}^{\prime}(0)+\bar{r}_{1}\right)}
$$

Now we have founded values $\bar{k}_{1}, \bar{k}_{3}$ and with help of the formula (16) we could get $\bar{k}_{2}$ :

$$
\bar{k}_{2}=\bar{k}_{1}\left(\frac{\bar{k}_{3}}{Y_{\text {interp }}^{\prime}(0)}-1\right)
$$

From here, we wrote a program in Mathematica (Wolfram Research) to find the kinetic parameters of the process. The program uses the exact solution to the differential equations discussed above as fitting function (Eq. 14). As (Eq. 14) asymptotically approaches 1 as time increases $\lim _{t \rightarrow \infty} Y(t)=1$, we added additional data points at a sufficiently long time with values equal 1 . Then we build interpolating function for experimental data with added some extra points at a sufficiently long time. We use this interpolating function for finding its first and second derivatives at time zero and logarithmic derivative of one minus interpolating function at a sufficiently long time. Obtained quantities allows us to calculate approximate values of needed parameters (Eq. 17, 19, 20), which were used on the next step as seed values for the kinetic parameters of the model. Finally, using Computational Intelligence Packages (CIP) for Mathematica, which implements the Levenberg-Marquardt algorithm, we found more precise parameters by non-linear fitting starting from these seed values and made to match our experimental data. This provided precise parameters for (Eq. 13, 14).

\section{Results and Discussion}

In our previous paper [13] we presented the data demonstrating that the earlier suggested by us mechanism of PRIGs nonspecific binding to an im- 


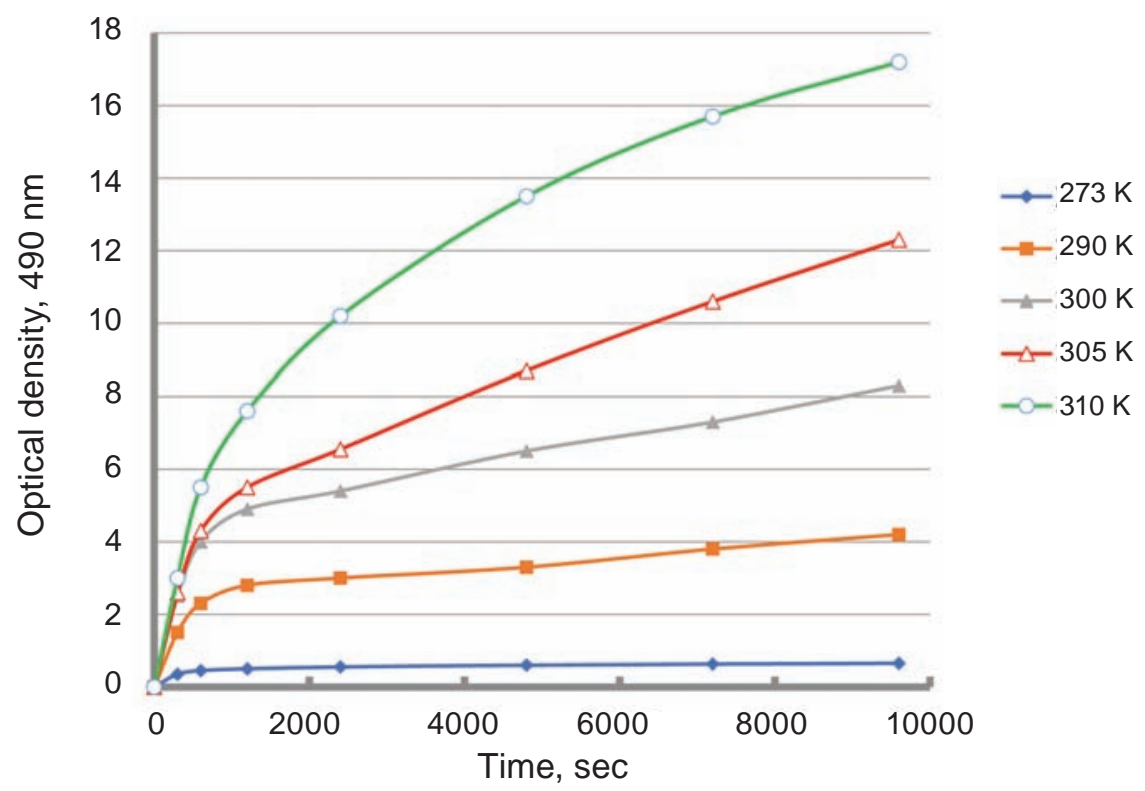

Fig. 1. Kinetic curves of PRIGs binding to immobilized antigen at different temperatures: 273, 290, 300, 305, and $310 \mathrm{~K}$

mobilized antigen allows determining the rate constants for each step of the process.

By doing measurements at different temperatures (Fig. 1), it was possible to determine the relations between rate constants and temperature (Table 1) and by utilizing presented above equations (1)-(13) to evaluate thermodynamic parameters of PRIG-antigen interaction.

From the above table it is obvious that the observed value of $k_{3}$ does not depend on the temperature. It does not increase with the increasing of the temperature and even has some tendency to diminish at temperatures higher than $290 \mathrm{~K}$. And conversely, the constants $k_{1}$ and $k_{2}$ gradually increase with temperature.

According to the Arrhenius' theory, the absence of the effect of temperature on the reaction rate most likely means that the activation energy of this

Ta ble 1. Rate constants of PRIGs binding to immobilized ovalbumin at different temperatures

\begin{tabular}{c|c|c|c}
\hline$T(\mathrm{~K})$ & $k_{1}\left(\mathrm{~s}^{-1}\right)$ & $k_{2}\left(\mathrm{~s}^{-1}\right)$ & $k_{3}\left(\mathrm{M} \times \mathrm{s}^{-1}\right)$ \\
\hline 273 & $8.9031 \mathrm{E}-07$ & $3.4000 \mathrm{E}-05$ & $3.7300 \mathrm{E}-03$ \\
290 & $1.81963 \mathrm{E}-05$ & $1.55600 \mathrm{E}-04$ & $4.87690 \mathrm{E}-03$ \\
300 & $2.99750 \mathrm{E}-05$ & $9.49800 \mathrm{E}-05$ & $2.64300 \mathrm{E}-03$ \\
305 & $8.00240 \mathrm{E}-05$ & $2.43694 \mathrm{E}-04$ & $2.71960 \mathrm{E}-03$ \\
310 & $2.04400 \mathrm{E}-04$ & $3.16340 \mathrm{E}-04$ & $1.75080 \mathrm{E}-03$ \\
\hline
\end{tabular}

reaction, $E_{\mathrm{a}}$, is close to zero and it does not need to overcome a potential barrier equal to the activation energy value for the interaction of the reacting molecules. In the above example, $k_{3}$ is the rate constant of the binding reaction between the activated PRIGs molecules and the antigen immobilized on the plate due to their hydrophobic interaction. Thus, we can assume, at least in this case, that the hydrophobic interaction between PRIGs and antigen is very little dependent on temperature, or that this relationship is more complex than the directly proportional dependence of the logarithm of the rate constant on the inverse value of temperature, expressed in Kelvin units. Note that similar patterns of hydrophobic interaction dependence on temperature were observed by other authors when studying completely different reagents and under different conditions [19, 20].

A completely different situation was found when we studied the dependence of $k_{1}$ and $k_{2}$ values on temperature. This allowed us to construct linear dependences corresponding to equations (1)-(11) and to determine the values of several thermodynamic parameters of the investigated process. Fig. 1 shows the dependence of the logarithms of the rate constants $k_{1}$ and $k_{2}$ on the inverse temperature according to Eq. (2):

As can be seen from Fig. 2 (and as it should be according to Eq. 2), the values of the logarithms of the rate constants $k_{1}$ and $k_{2}$ are proportional to the inverse of the reaction temperature, expressed in 


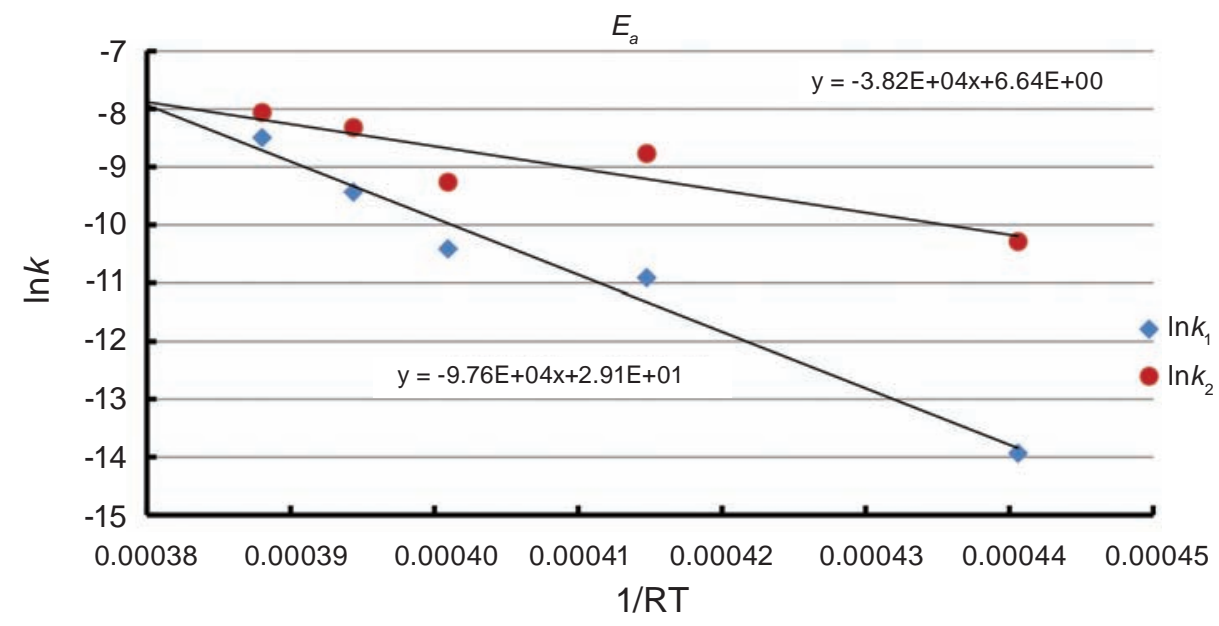

Fig. 2. Linear dependences between the logarithms of the rate constants $k_{1}$ and $k_{2}$ and the inverse values of the reaction temperature, expressed in degrees Kelvin

degrees Kelvin and multiplied by the value of the gas constant, $R$. Due to this fact, we obtained linear dependences, the negative values of the tangents of the slope which are equal to the activation energy of these processes, $E_{\mathrm{a}}$, could be easy to calculate. Using Microsoft Excel, we found that for the PRIGs "activation" process, the equation for the linear relationship between $\ln \left(k_{1}\right)$ and $1 /(R T)$ is $y=-97600 x+29.1$, and for the reverse process, i.e. for the "inactivation” of the PRIG, the linear dependence of $\ln \left(k_{2}\right)$ on $1 /(R T)$ will be represented by the equation $y=-38200 x+6.64$. Consequently, $E_{\mathrm{a}}$ for "activation" of PRIGs is $97600 \mathrm{~J} \times \mathrm{mol}^{-1}$, and for the process of “inactivation” of PRIGs $E_{\mathrm{a}}=38200 \mathrm{~J} \times \mathrm{mol}^{-1}$.

It is important to notice that constant $k_{1}$ increases much faster with increasing temperature than $k_{2}$ (Table 1). For this reason, the equilibrium constant of the PRIG "activation" process, $K_{\mathrm{e}}$, equal to the ratio of $k_{1}$ to $k_{2}$, is almost ten times higher at $310 \mathrm{~K}$ than at $273 \mathrm{~K}$ (Table 2). Consequently, as the temperature increases, the proportion of PRIGs molecules that are "activated", i.e., exhibit hydrophobic sites on their surface and, due to this, are capable of non-specific binding to antigens, increases significantly. Using Eq. (6) we can also determine the $\Delta \mathrm{G}^{\circ}$ values for the transformation of PRIGs into "active" molecules at different temperatures (Table 2). As can be seen from Table $2, \Delta \mathrm{G}^{\circ}$ values stay positive at all temperatures. This suggests that the PRIG "activation-inactivation" process is sharply shifted toward the formation of "inactive" molecules, i.e., those that do not expose hydrophobic sites on their surface.

It important to remember that the $\Delta \mathrm{G}^{\circ}$ value is several times lower at $310 \mathrm{~K}$ than at $273 \mathrm{~K}$. This suggests that as the temperature rises to $310 \mathrm{~K}$, the appearance of "active” PRIGs becomes much more likely than at $273 \mathrm{~K}$. As a result, the portion of "active” PRIGs increases drastically with temperature increase leading to dramatic increase in the rate of PRIGs binding to the immobilized antigen.

Furthermore, we can determine the values of $\Delta \mathrm{H}^{\circ}$ and $\Delta \mathrm{S}^{\circ}$ for the PRIG "activation" process from equations (9) and (10). Fig. 3 shows the dependency of $T_{1} T_{2} \ln \frac{K_{e 2}}{K_{e 1}}$ on the value of $\left(T_{2}-T_{1}\right)$. According to equation (9), the tangent of the angle of the obtained linear dependency is $\Delta \mathrm{H}^{\circ}$. Using the Microsoft Excel program, it is easy to determine that in this case $\Delta \mathrm{H}^{0}=59895 \mathrm{~J} \times \mathrm{M}^{-1}$. Thus, the values of enthalpy of the reaction of "activation" of PRIGs molecules, i.e. induction of appearance of hydrophobic sites on the surface of a protein molecule in hydrophilic medium, which are normally hidden inside the molecule, shows us that it is a very energy-consuming process.

Using similar approach, we can determine the values of $\Delta S^{\circ}$ for the "activation" process of

Table 2. The values of $K_{e}$ and $\Delta G^{o}$ for PRIGs transformation from "inactive" into "active" state

\begin{tabular}{c|c|c}
\hline$t(\mathrm{~K})$ & $k_{1} / k_{2}=K_{\mathrm{e}}$ & $\Delta \mathrm{G}^{\circ}(\mathrm{J})$ \\
\hline 273 & $3.4000 \mathrm{E}-05$ & 8267.6 \\
290 & $1.55600 \mathrm{E}-04$ & 5174.3 \\
300 & $9.49800 \mathrm{E}-05$ & 2876.6 \\
305 & $2.43694 \mathrm{E}-04$ & 2823.8 \\
310 & $3.16340 \mathrm{E}-04$ & 1125.6 \\
\hline
\end{tabular}



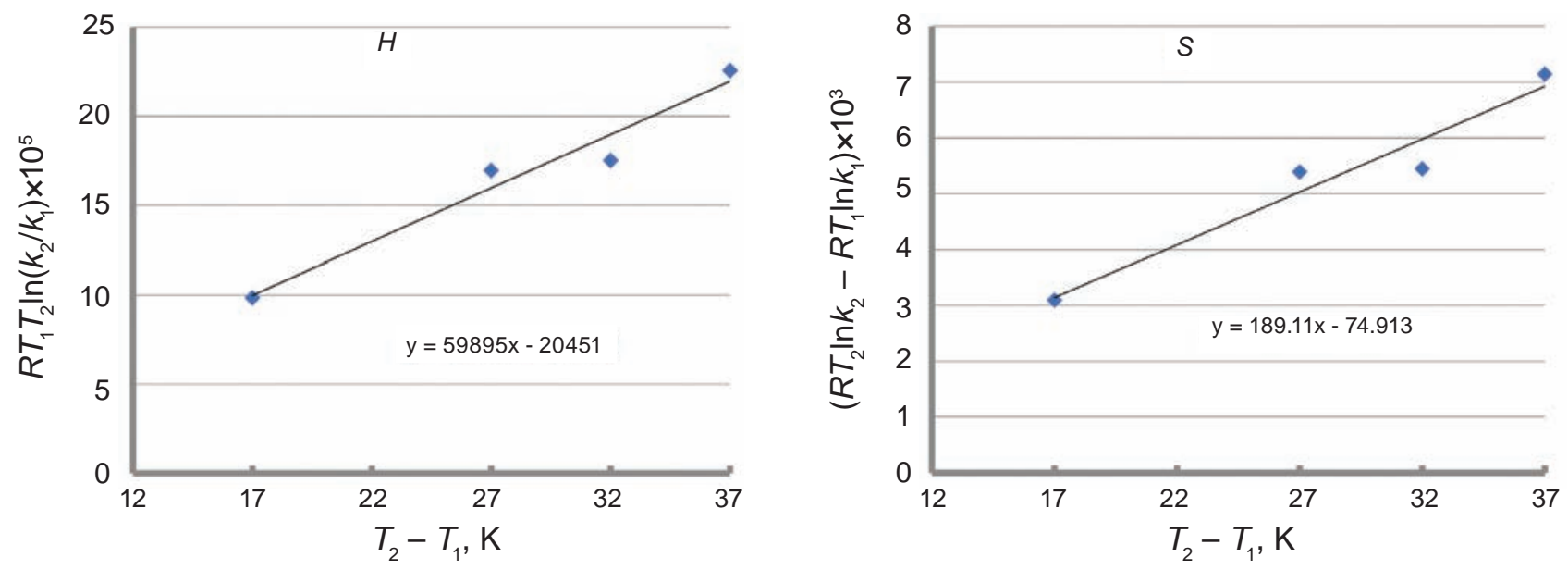

Fig. 3. Evaluation of the values of $\Delta H^{\circ}$ and $\Delta S^{\circ}$ for the PRIG "activation" process according to Eqs. (9) and (10)

PRIGs molecules, based on the linear dependence of $R T_{2} \ln K_{\mathrm{e} 2}-R T_{1} \ln K_{\mathrm{e} 1}$ on $\left(T_{2}-T_{1}\right)$ according to equation (10). In this case, we find that the change in entropy under standard conditions $\Delta \mathrm{S}^{0}=189 \mathrm{~J} \times \mathrm{M}^{-1} \times \mathrm{grad}^{-1}$ (i.e., entropy units), which is also a very significant value. In other words, structural changes in the polypeptide PRIG chain stacking occur as a result of which hydrophobic sites briefly appear on the surface of the molecule, and this process, according to our calculations, is accompanied by a significant increase in entropy.

Thus, using the previously proposed model of the nonspecific reaction of interaction of PRIGs with antigens and the series of kinetic curves of PRIGs binding to immobilized antigen at various temperatures obtained in the experiment, we managed to find the rate constants of individual stages of the considered process, and also determine the thermodynamic characteristics of each of the stages. We hope that the data obtained will allow for a better understanding of the process of non-specific PRIG binding to a variety of antigens. Assuming that this interaction also occurs in vivo, the data obtained may also be of certain biological significance.

In addition, as we have already mentioned in a previous article [13], the process of PRIGs binding to antigen is similar to nonspecific aggregation of various proteins in solutions. Like the process of interaction of PRIGs with the antigen, the processes of protein aggregation are highly dependent on the temperature of the solution. In this connection, it is possible to assume that the regularities of PRIGs "activation" and subsequent PRIGs binding to antigen can be similar to the processes of protein aggregation. Methods used in this article can be ap- plied to solve practical problems for example to find ways to store proteins in solutions and to minimize irreversible aggregation of these proteins during storage.

Conflict of interest. Authors have completed the Unified Conflicts of Interest form at http://ukrbiochemjournal.org/wp-content/uploads/2018/12/ coi_disclosure.pdf and declare no conflict of interest.

Funding. The work was suppoted by budget costs of National Academy of Sciences of Ukraine, project N 0119U002511.

\section{ТЕРМОДИНАМІКА ВЗАЕМОДІЇ МІЖ ПОЛІРЕАКТИВНИМИ ІМУНОГЛОБУЛІНАМИ \\ ТА ІММОБІЛІЗОВАНИМИ АНТИГЕНАМИ}

\section{С. А. Бобровник $\kappa^{1 凶}$ О. В. Оглобля ${ }^{2}$, М. О. Демченко ${ }^{1}$, С. В. Комісаренко}

$$
\begin{gathered}
{ }^{1} \text { Інститут біохімії ім. О. В. Палладіна } \\
\text { НАН України, Київ; } \\
{ }^{2} \text { Ннц Інститут біології та медицини, } \\
\text { Київський національний університет } \\
\text { iмені Тараса Шевченка, Україна; } \\
\text { घe-mail: s-bobrov@ukr.net }
\end{gathered}
$$

Для визначення термодинамічних параметрів взаємодії між поліреактивними імуноглобулінами (ПРІГ) і іммобілізованим антигеном, було одержано кілька експериментальних кінетичних кривих зв'язування ПРГ із іммобілізованим овальбуміном за різних температур. Це дозволило визначити константи швидкості 
для кожного етапу процесу взаємодії для кожної температури. Потім за допомогою відповідних рівнянь було розраховано такі термодинамічні параметри, як енергія активації, ентальпія, ентропія і стандартна вільна енергія (енергія Гіббса). Знайдені термодинамічні величини показують, що найенергетичнішим затратним кроком процесу зв'язування ПРІГ 3 іммобілізованим антигеном є трансформація «неактивних» молекул ПРІГ в «активні», тобто утворення гідрофобних областей на поверхні ПРІГ. І навпаки, наступний крок взаємодії, а саме зв'язування «активних» ПРІГ із іммобілізованим антигеном $\epsilon$ енергетично незалежним.

К л ю ч о в і с ло в а: поліреактивні імуноглобуліни, антигени, кінетика взаємодії, константи швидкості, термодинамічні параметри.

\section{References}

1. Berzofsky JA, Berkover AJ. Antibody-antigen interaction. Fundamental Immunology. Ed. by Paul WE., 1989, Raven Press, New York, P. 3-88.

2. Milling S. The importance of polyreactive antibodies in protection against pneumococcal infection. Immunology. 2021; 162(4): 339-340.

3. Machado H, Figueiredo LM. Polyreactive antibodies bridge immunity particles to pathogen. Trends Parasitol. 2020; 36(10): 804-806.

4. Gunti S, Herman SEM, Gottumukkala RVSRK, Xiong Y, Sun C, Carmona GN , Wiestner A, Notkins AL. Polyreactive antibodies in CLL correlate with the level of immunoglobulins not the number of B lymphocytes. Leuk Lymphoma. 2019; 60(1): 242-245.

5. Liao H, Zhang Z. Polyreactive Antibodies in Anti-HIV-1 Responses. Curr Mol Med. 2018; 18(2): 126-133.

6. Bunker JJ, Erickson SA, Flynn TM, Henry C, Koval JC, Meisel M, Jabri B, Antonopoulos DA, Wilson PC, Bendelac A. Natural polyreactive IgA antibodies coat the intestinal microbiota. Science. 2017; 358(6361): eaan6619.

7. Liao H, Yu Y, Li S, Yue Y, Tao C, Su K, Zhang Z. Circulating Plasmablasts from Chronically Human Immunodeficiency VirusInfected Individuals Predominantly Produce Polyreactive/Autoreactive Antibodies. Front Immunol. 2017; 8: 1691.
8. Zorn E, See SB. Polyreactive natural antibodies in transplantation. Curr Opin Organ Transplant. 2017; 22(1): 8-13.

9. Lecerf M, Jarossay A, Kaveri SV, LacroixDesmazes S, Dimitrov JD. Methods for Posttranslational Induction of Polyreactivity of Antibodies. Methods Mol Biol. 2017; 1643: 135145.

10. Gunti S, Notkins AL. Polyreactive Antibodies: Function and Quantification. J Infect Dis. 2015; 212(Suppl 1): S42-S46.

11. Mahendra A, Gangadharan B, André S, Boudjoghra M, Davi F, Lecerf M, Planchais C, Kaveri SV, Lacroix-Desmazes S, Dimitrov JD. Cryptic polyreactivity of IgG expressed by splenic marginal zone B-cell lymphoma. Mol Immunol. 2014; 60(1): 54-61.

12. Bobrovnik SA. Polyreactive immunoglobulins: molecular properties and functions. Comments Mol Cell Biophys. 1999; 9(6): 323-356.

13. Bobrovnik SA, Ogloblya OV, Demchenko MO, Komisarenko SV. Kinetics of interaction between polyreactive immunoglobulins and antigen. Ukr Biochem J. 2020; 92(5): 15-22.

14. Bobrovnik SA. Polyreactive immunoglobulins recognize hydrophobic parts of proteins. $U \mathrm{kr}$ Biokhim Zhurn. 2001; 73(2): 116-122. (In Russian).

15. Bobrovnik SA, Demchenko MO, Komisarenko SV. Interaction peculiarities of polyreactive immunoglobulins and various antigens. Ukr Biochem J. 2014; 86(1): 8-74.

16. Bobrovnik SA. Mechanism of interaction between polyreactive immunoglobulins and protein antigens. Ukr Biokhim Zhurn. 2002; 74(2): 37-44.

17. Bobrovnik SA. Determination of antibody affinity by ELISA. Theory. J Biochem Biophys Methods. 2003; 57(3): 213-236.

18. Chang R. Physical chemistry with applications to biological systems. Macmillan Publishing Co., Inc. New York, 1977.

19. Koshlan TV, Kulikov KG. Mathematical modeling of the effect of temperature on the nature of binding of monomeric proteins in aqueous solutions. $J$ Tech Physics. 2017; 87(11) 1734-1741. (In Russian).

20. Kazemi M, Åqvist J. Chemical reaction mechanisms in solution from brute force computational Arrhenius plots. Nat Commun. 2015; 6: 7293. 